\title{
A survey of the ichthyofauna in the Noetsie Estuary, Western Cape Province, South Africa
}

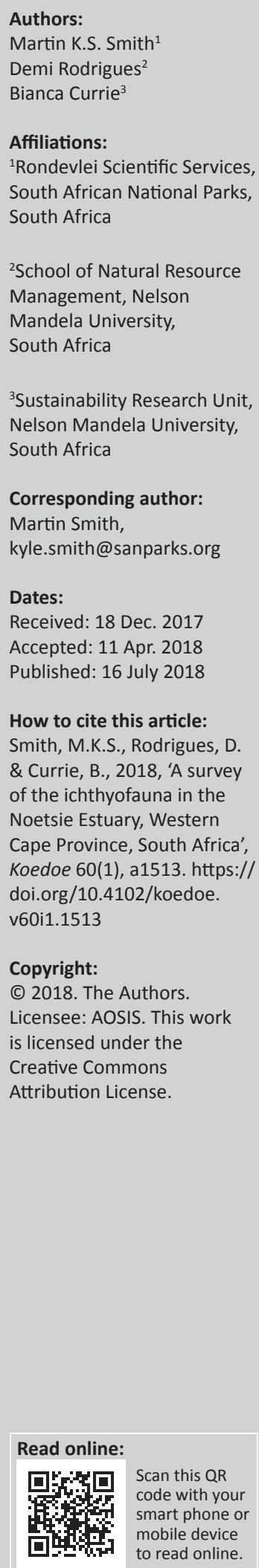

${ }^{3}$ Sustainability Research Unit, Nelson Mandela University, South Africa

Corresponding author: Martin Smith, kyle.smith@sanparks.org

The fish assemblage in the Noetsie Estuary, a temporarily open and closed estuary on the southern coast of South Africa, was sampled using multiple gears. A total of 12 species from 8 families were recorded. Collectively, estuarine-dependent marine species dominated seine net catches numerically and in terms of biomass for both sampling seasons. Estuarine round herring (Gilchristella aestuaria) was numerically the dominant species in late summer, while juvenile Mugilidae dominated catches in winter. Size class distributions of various fish species indicate that the estuary both serves a nursery function for important euryhaline marine species and supports estuarine resident taxa. Application of the Estuarine Fish Community Index indicates the ecological condition of the estuary to be 'good'. This study contributes to the species list for the estuary while also reporting the presence of an alien invasive freshwater species, Gambusia affinis. Recommendations include the development of a management plan and the formalisation of an estuarine management committee.

Conservation implications: The Noetsie Estuary serves a nursery function for important euryhaline marine species, while supporting healthy populations of estuarine resident taxa. The presence of one alien invasive fish species is documented with potential implications for the conservation of biodiversity in the estuary.

\section{Introduction}

South Africa has approximately 300 estuaries along its coastline (Whitfield 2000). Collectively, they play an important role in promoting fish species richness in South Africa (Harrison 2003) and are important nursery areas for several species of marine fishes, many of which are exploited (James \& Harrison 2008). The ichthyofauna in estuaries along the southern coast of South Africa is fairly well known (Hall, Whitfield \& Allanson 1987; James \& Harrison 2008; Kok \& Whitfield 1986; Olds et al. 2011; Russell 1996; Whitfield \& Kok 1992). In a review, James et al. (2007) showed that the fish fauna in southern coast estuaries are dominated by juvenile estuary-dependent marine species, with strong contributions by Mugilidae and Sparidae. Native estuarine resident species are also abundant in most estuaries in this region (James \& Harrison 2008), but a number of smaller estuaries, including the Noetsie, are data deficient (Whitfield 2000).

Anthropogenic influences on estuarine environments can impact food resources, distribution, breeding, growth and survival of fish assemblages (Whitfield \& Elliott 2002). Despite the dynamic nature of fish assemblages within estuaries, fish communities have been used as indicators of estuary health (Harrison \& Whitfield 2004) and can illustrate changes in the condition of estuarine environments (Whitfield 1997). The Estuarine Fish Community Index (EFCI) is a multi-metric fish index that integrates structural and functional attributes of estuarine fish communities to provide a robust method for assessing the ecological condition of estuarine systems (Harrison \& Whitfield 2004). Understanding and being aware of changes in relative abundance and species composition is important for guiding and evaluating management actions (Olds et al. 2016) as they can reflect the state of the estuary and impact of management interventions.

Here we assess the diversity, abundance and size structure of the fish community within the Noetsie Estuary and compare the current EFCI scores with a previous assessment (Harrison \& Whitfield 2006b).

\section{Materials and methods}

\section{Study site}

The Noetsie Estuary, situated just east of Knysna, borders the Garden Route National Park (Figure 1) and falls within the warm-temperate bioregion (Harrison 2003). Classified as a 


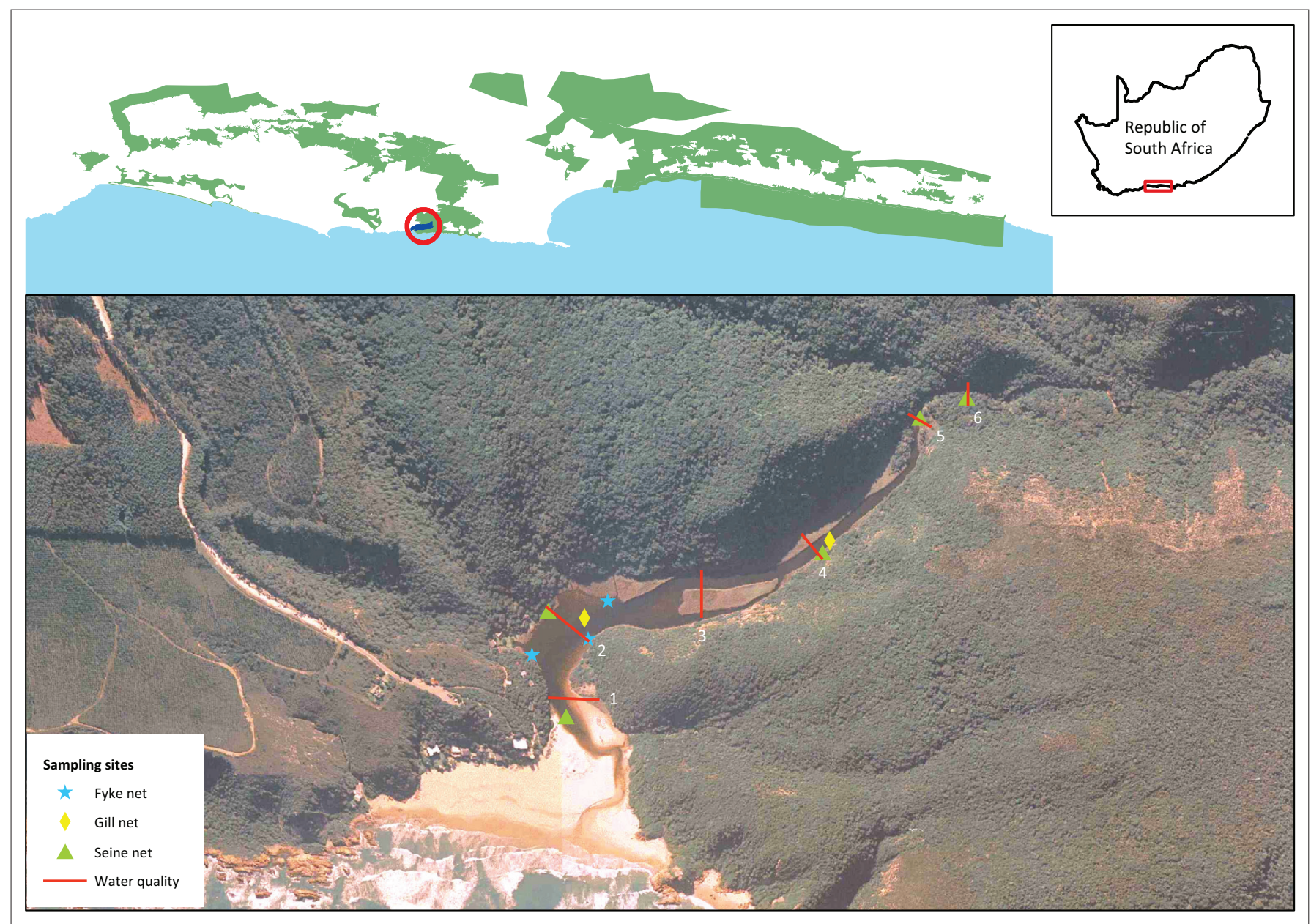

FIGURE 1: Map of the Noetsie Estuary in relation to the Garden Route National Park and placement of sampling positions.

temporarily open and closed system, the overall condition is considered excellent (Whitfield 2000) and the ecological state is defined as largely natural with few modifications (DWAF 2008). However, based on the fish community, Harrison and Whitfield (2006b) rated the system as 'poor'. The Noetsie River has a total catchment of $38.8 \mathrm{~km}^{2}$ (NRIO 1987) and is one of the few estuaries that receives most of its natural mean annual run-off (Bornman \& Adams 2005).

\section{Physico-chemical properties}

During each survey, selected physico-chemical parameters including water temperature $\left({ }^{\circ} \mathrm{C}\right), \mathrm{pH}$, salinity (\%o) and dissolved oxygen $\left(\mathrm{mg} \mathrm{L}^{-1}\right)$ were measured at six sites situated up the estuary (Figure 1). All readings were taken at the surface using a multi-parameter water analyser (YSI 550A Dissolved Oxygen; YSI Model 60 Handheld $\mathrm{pH}$ and Temperature; YSI Model 30 Handheld Salinity, Conductivity and Temperature instrument).

\section{Ichthyofauna}

Sampling was conducted in late summer (March) and winter (July) of 2015. Fish were sampled in the main channel of the estuary using a $30 \mathrm{~m}$ beach seine net $(30 \mathrm{~m} \times 2 \mathrm{~m} \times 15 \mathrm{~mm}$ multifilament bar mesh in the wings and $5 \mathrm{~mm}$ bar mesh in the purse) at five sites spaced longitudinally up the estuary (Figure 1). Dense stands of common reeds (Phragmites australis) in the lower and middle reaches as well as steep sides and dense bush in the upper reaches limited beach seine net sites. One seine net pull was executed at each site on each sampling excursion. At each site, a scoop net $(54 \mathrm{~cm}$ diameter hoop and $2 \mathrm{~mm}$ bar mesh) was also used to sample the shallows along roughly $15 \mathrm{~m}$ of shoreline (three samples each of $5 \mathrm{~m}$ ).

A multi-mesh multifilament gillnet (stretched mesh sizes: $35 \mathrm{~mm}, 45 \mathrm{~mm}, 57 \mathrm{~mm}, 73 \mathrm{~mm}, 93 \mathrm{~mm}, 118 \mathrm{~mm}$ and $150 \mathrm{~mm}$ ) with each panel being $5 \mathrm{~m}$ long was deployed for 2 hours at two sites, one middle and one lower (Figure 1).

Three double-ended fyke nets $(10 \mathrm{~mm}$ stretched mesh, $5 \mathrm{~m}$ leader and $60 \mathrm{~cm}$ first hoop diameter) were set within the lower reaches of the estuary (Figure 1) parallel to the shoreline. Fyke nets were set at sunset in water approximately $1 \mathrm{~m}$ deep and retrieved the following day at sunrise.

All fish caught were identified to the lowest possible taxonomic level and measured to the nearest millimetre fork length (FL) before being released. Mullet (Mugilidae) caught below $80 \mathrm{~mm}$ were only recorded at family level. 


\section{Data analysis}

Diversity was calculated as the total number of species and the number of species sampled per sampling trip. Total species composition, by number and mass, was calculated for each sampling period with the relative biomass contribution of each species calculated using masses derived from lengthmass relationships presented in Harrison (2001). Where appropriate, species length-frequency histograms $(20 \mathrm{~mm}$ size classes for Lichia amia and $10 \mathrm{~mm}$ size classes for all other species) were generated for each sampling trip. Species recorded were divided into the estuarine association categories described by Whitfield (1994): freshwater species, estuarine resident species, estuarine-dependent marine species and marine species. The per cent contribution made by each category to the total ichthyofaunal assemblage of each sampling trip was calculated in terms of number of species, relative abundance and relative mass.

\section{Estuarine Fish Community Index}

The EFCI developed by Harrison and Whitfield (2004) comprises 14 metrics that represent four broad fish community attributes: species diversity and composition, species abundance, nursery function and trophic integrity (Table 1). Metric reference conditions applicable to the Noetsie Estuary were developed from Table 5 presented in Harrison and Whitfield (2006a) and followed procedures set out in Harrison and Whitfield (2006b). Each metric was assessed according to the extent of its deviation from the reference condition with thresholds and scores being based on Harrison and Whitfield (2006b) (Table 1). The species assemblage was compared to the reference assemblage using the Bray-Curtis similarity measure based on presence or absence. Relative (\%) contribution of each species for each sampling period and reference assemblage was 4th root transformed prior to running the Bray-Curtis similarity measure. For both these analyses, Mugilidae were included as a 'species' because of the large proportion of juvenile mullet that were not identified down to species level. The final EFCI score was calculated by summing the various scores. The biological condition of the estuary was designated a qualitative rating (very poor to very good) based on ranges described in Harrison and Whitfield (2006b). The EFCI was applied to the late summer and winter data sets, and final scores were compared to an assessment by Harrison and Whitfield (2006b). Bray-Curtis similarity analyses were performed using the Plymouth Routines in Multivariate Ecological Research package (PRIMER) (Clarke \& Warwick 1994).

\section{Results}

\section{Physico-chemical}

Surface water temperature ranged between $18.9^{\circ} \mathrm{C}$ and $22.6^{\circ} \mathrm{C}$ during late summer and $11.3^{\circ} \mathrm{C}$ and $13.2^{\circ} \mathrm{C}$ in winter with only a slight drop in temperature occurring in the upper reaches for both sampling periods. Salinity was low throughout the estuary during late summer decreasing from
TABLE 1: Metric scoring criteria for small closed estuaries in the warm-temperate biogeographic region.

\begin{tabular}{|c|c|c|c|}
\hline \multirow[t]{2}{*}{ Estuarine Fish Community Index Metric } & \multicolumn{3}{|c|}{ Score } \\
\hline & 5 & 3 & 1 \\
\hline \multicolumn{4}{|l|}{ Species diversity and composition } \\
\hline 1. Total number of taxa & $>12.0$ & $12-7$ & $<7.0$ \\
\hline 2. Rare or threatened species & present & absent & \\
\hline 3. Exotic or introduced species & - & absent & present \\
\hline $\begin{array}{l}\text { 4. Species composition } \\
(\% \text { similarity to reference })\end{array}$ & $\geq 80.0$ & $<80.0$ and $\geq 50.0$ & $<50.0$ \\
\hline \multicolumn{4}{|l|}{ Species abundance } \\
\hline $\begin{array}{l}\text { 5. Number of species that make } \\
\text { up } 90 \% \text { of the abundance }\end{array}$ & $>4.0$ & $4.0-3.0$ & $<3.0$ \\
\hline $\begin{array}{l}\text { 6. Species relative abundance } \\
\text { (\% similarity to reference) }\end{array}$ & $\geq 60.0$ & $<60.0$ and $\geq 40.0$ & $<40.0$ \\
\hline \multicolumn{4}{|l|}{ Nursery function } \\
\hline 7. Number of estuarine resident taxa & $>3.0$ & $3.0-2.0$ & $<2.0$ \\
\hline $\begin{array}{l}\text { 8. Number of estuarine-dependent } \\
\text { marine taxa }\end{array}$ & $>8.0$ & $8.0-5.0$ & $<5.0$ \\
\hline $\begin{array}{l}\text { 9. Relative abundance of estuarine } \\
\text { resident taxa }(\%)\end{array}$ & $25.0-75.0$ & $\begin{array}{l}\geq 10.0 \text { and }<25.0 \text { or } \\
>75.0 \text { and } \leq 90.0\end{array}$ & $\begin{array}{l}<10.0 \text { or } \\
>90.0\end{array}$ \\
\hline $\begin{array}{l}\text { 10. Relative abundance of estuarine- } \\
\text { dependent marine taxa }(\%)\end{array}$ & $25.0-75.0$ & $\begin{array}{l}\geq 10.0 \text { and }<25.0 \text { or } \\
>75.0 \text { and } \leq 90.0\end{array}$ & $\begin{array}{l}<10.0 \text { or } \\
>90.0\end{array}$ \\
\hline \multicolumn{4}{|l|}{ Trophic integrity } \\
\hline $\begin{array}{l}\text { 11. Number of benthic invertebrate } \\
\text { feeding taxa }\end{array}$ & $>3.0$ & $3.0-2.0$ & $<2.0$ \\
\hline 12. Number of piscivorous taxa & $>1.0$ & 1.0 & $<1.0$ \\
\hline $\begin{array}{l}\text { 13. Relative abundance of benthic } \\
\text { invertebrate feeding taxa }(\%)\end{array}$ & $>2.0$ & $2.0-1.0$ & $<1.0$ \\
\hline $\begin{array}{l}\text { 14. Relative abundance of } \\
\text { piscivorous taxa }(\%)\end{array}$ & $>0.5$ & $0.5-0.1$ & $<0.1$ \\
\hline
\end{tabular}

Source: Adapted from Harrison, T.D. \& Whitfield, A.K., 2006b, 'Application of a multimetric fish index to assess the environmental condition of South African estuaries', Estuaries and Coasts 29, 1108-1120. https://doi.org/10.1007/BF02781813

Note: Metrics 1, 5, 7, 8, and 11-14 have region-specific values (warm-temperate), while other metrics are expressed as absolute values or as percentages of reference conditions.

$1.7 \%$ near the mouth to $0.2 \%$ at sites five and six. The estuary mouth was open during the winter sampling period, and a salinity gradient was present with the highest salinity (17.2\%o) occurring near the mouth and the lowest $(0.4 \%$ o recorded at transect six. Surface water $\mathrm{pH}$ was relatively constant throughout the estuary during late summer ranging between 7.59 near the mouth and 7.02 at site six. During winter, the $\mathrm{pH}$ was generally lower and ranged from 5.95 near the mouth up to 6.59 at transect five. Oxygen levels in late summer showed a slight increase from transect one (4.65 $\left.\mathrm{mg} \mathrm{L}^{-1}\right)$ to transect five $\left(6.60 \mathrm{mg} \mathrm{L}^{-1}\right)$ but varied between transects in winter with the lowest level $\left(4.66 \mathrm{mg} \mathrm{L}^{-1}\right)$ recorded at transect five and the highest $\left(8.88 \mathrm{mg} \mathrm{L}^{-1}\right)$ recorded in the lower reaches.

\section{Ichthyofauna}

A total of 731 fish representing 12 species and 9 families were sampled. Of these, one was catadromous (category V), two were estuarine residents (category I), eight were marine migrants (category II) and one was a freshwater species (category IV) (Table 2).

Seine net catches were dominated numerically by Gilchristella aestuaria and Mugilidae (unidentified mullet species) comprising $37.8 \%$ and $30.8 \%$ of total catch in late summer respectively. However, Mugilidae dominated catches (31.6\%) during winter followed by G. aestuaria (25.8\%). Euryhaline marine species (categories IIa, IIb and IIc) contributed $54.3 \%$ 
TABLE 2: Relative abundance and biomass of fishes captured during surveys conducted in the Noetsie Estuary between late summer and winter 2015.

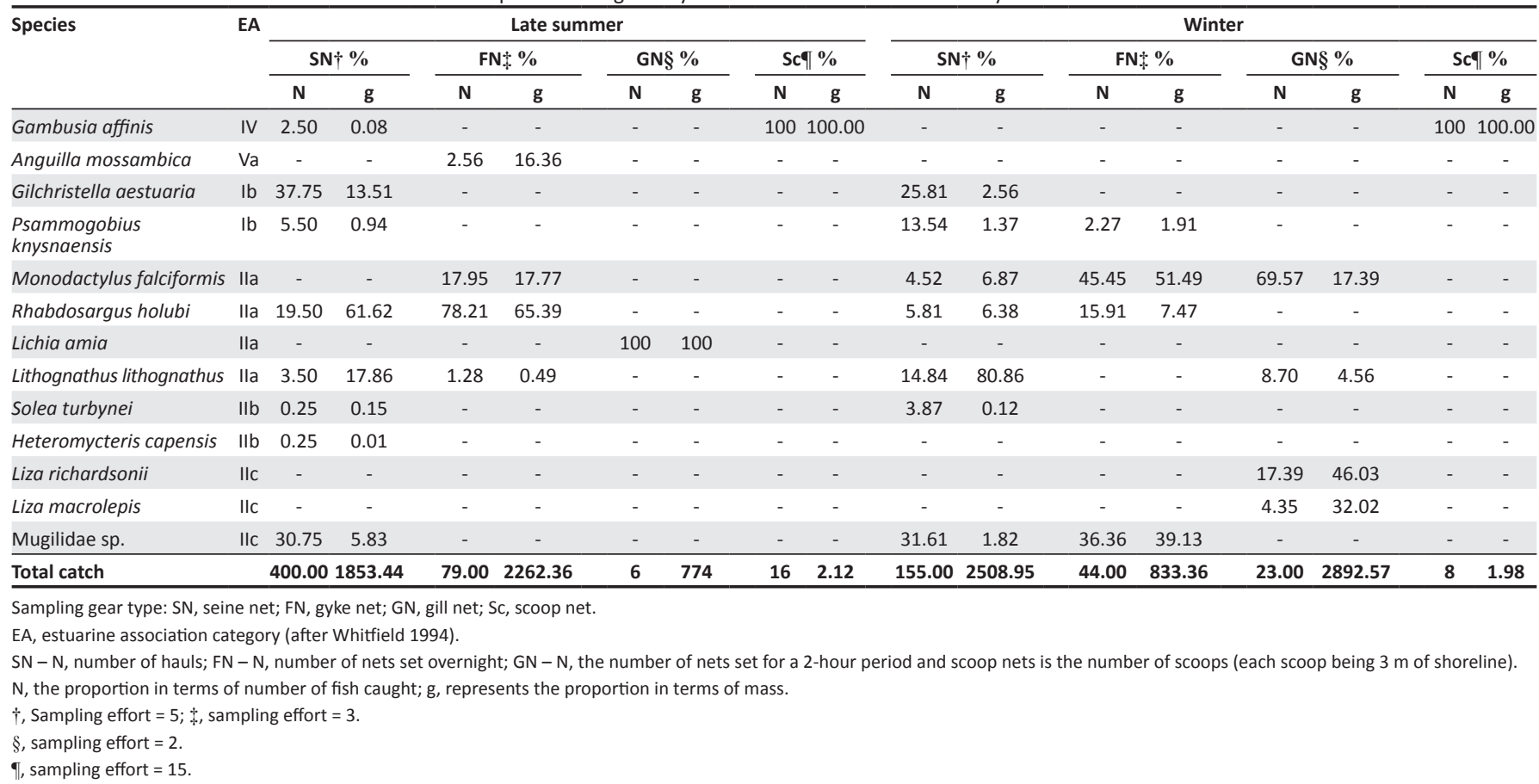

and $56.1 \%$ of total numbers of fish caught during the late summer and winter sampling trips, respectively, and dominated catches in terms of biomass comprising $85.5 \%$ and $60.7 \%$ of the entire sampled biomass, respectively (Table 2). Although estuarine resident species $(\mathrm{Ib})$ were prominent in terms of numbers together comprising $43.3 \%$ and $28.4 \%$ of the total number of fish caught during late summer and winter, respectively, they only contributed $14.5 \%$ and $3.9 \%$ of the total biomass harvested. Fyke net catches in late summer were dominated by Rhabdosargus holubi (78.2\%) both numerically and in terms of biomass (65.4\%), while winter catches were dominated by Monodactylus falciformis (Table 2). One species, Anguilla mossambica, sampled in late summer, was not caught in any other gear type. Lichia amia was the only species caught within the gill nets (Table 2) during late summer, while M. falciformis $(69.6 \%)$ dominated gill net catches numerically during winter followed by Liza richardsonii (17.4\%). Scoop netting only resulted in one species, Gambusia affinis, being caught during both sampling periods with fewer and smaller individuals being caught in winter (Table 2).

\section{Length-frequency distributions}

The length-frequency distribution for G. aestuaria showed a high proportion of adult fish in the $50 \mathrm{~mm}-70 \mathrm{~mm}$ (FL) size range during both late summer and winter with very few larger individuals or juveniles present during the late summer period (Figure 2). Lichia amia were only sampled during late summer with fish ranging in size from $440 \mathrm{~mm}$ FL to $515 \mathrm{~mm}$ FL. Most Mugilidae sampled during the two surveys were juveniles ranging in size from $11 \mathrm{~mm}$ to $71 \mathrm{~mm}$ FL (Figure 2). A greater distribution in size frequency for Mugillids was noted during late summer. Lithognathus lithognathus showed a shift in size class distribution between late summer and winter with larger individuals being sampled in winter (Figure 2). Both R. holubi and M. falciformis showed a wider size frequency distribution in late summer compared to winter with the larger size classes absent during the second sampling period (Figure 2).

\section{Estuarine Fish Community Index}

The total EFCI score for the late summer sampling period was 49 , while the winter sampling scored 46 . The final index scores of both correspond to a qualitative rating of good (scores fall between 46 and 62) (Harrison \& Whitfield 2006b).

\section{Discussion}

Although temperature gradients along the length of small temporarily open and closed estuaries do not generally occur during their closed phase (Perissinotto et al. 2004), a difference of $3.4^{\circ} \mathrm{C}$ was recorded during the late summer survey. Rainfall experienced just prior and during the sampling period lead to increased river inflow which is likely to have influenced both water temperatures in the upper sections and the lower salinity levels recorded throughout the estuary during late summer. Bornman and Adams (2005) indicate that limnetic conditions $(0.1 \mathrm{ppt}-0.5 \mathrm{ppt})$ may prevail in the Noetzie Estuary through most of a closed phase. Although the lowest $\mathrm{pH}$ was recorded at transect five, near one of the main tributaries, $\mathrm{pH}$ was generally higher during the late summer survey. This is unusual as freshwater, because of the humic acid leached from catchment vegetation (DWAF 1995), is generally more acidic than sea water. Dissolved oxygen levels were generally lower than those reported by James and Harrison (2008) (6.2 $\left.\mathrm{mg} \mathrm{L}^{-1}-6.6 \mathrm{mg} \mathrm{L}^{-1}\right)$.

This survey recorded 12 species from 8 families, which is a substantial increase from the previous work by James and 

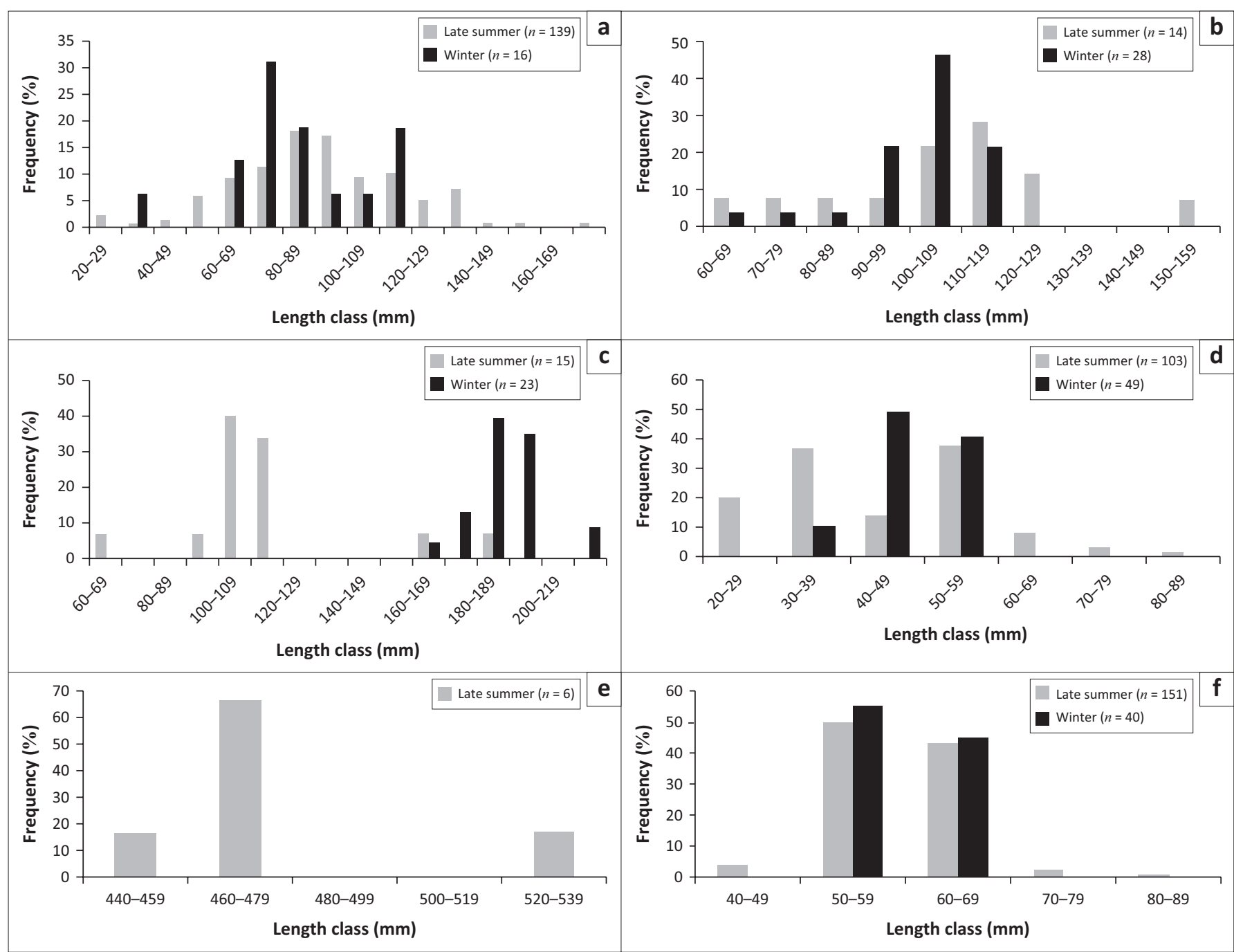

FIGURE 2: Length-frequency distribution of the more abundant species caught within the Noetsie Estuary. (a) Rhabdosargus holubi, (b) Monodactylus falciformis, (c) Lithognathus lithognathus, (d) Mugilidae, (e) Lichia aestuaria and (f) Gilchristella aestuaria.

Harrison (2008) during which 7 species from 4 families were recorded. Additional species include L. amia, M. falciformis, A. mossambica and L. macrolepis, which are all species known to occur within southern Cape estuarine systems (James \& Harrison 2008; Olds et al. 2011; Whitfield 1998). However, two species, Mugil cephalus and Myxus capensis, sampled by James and Harrison (2008) were not sampled during this survey. In addition, one alien invasive species, Gambusia affinis, was recorded for the first time within the system.

The numerical dominance of an estuarine resident species, in this case G. aestuaria, is not surprising as this group generally comprise over $50 \%$ of catches (numbers) in warm-temperate temporarily open and closed estuaries (James et al. 2007). Gilchristella aestuaria breed throughout the year completing their entire life cycle within the estuary (Whitfield 1998), and although the majority of G. aestuaria sampled were mature individuals; a wide range of size classes were sampled indicating that breeding was occurring within the estuary during the closed phase. Somewhat surprisingly, no Atherina breviceps were sampled during this or previous surveys (James \& Harrison 2008). Although there is an overlap in diet between the two species (Whitfield 1998), G. aesturia has been shown to switch diets and feeding strategies dependent on water clarity and food resources (Blaber, Cyrus \& Whitfield 1981) which may provide a competitive edge in certain circumstances. Atherina breviceps was among the most abundant species captured in adjacent estuaries both to the west (James \& Harrison 2008) and to the east of the Noetsie (James \& Harrison 2010); however, although the frequency of occurrence within small closed estuaries in the warmtemperate region is quite high at $60 \%$, the relative abundance is usually low at $4.98 \%$ (Harrison \& Whitfield 2006a). Determining the reasons for their omission from Noetsie Estuary requires further work but is probably because of environmental preferences rather than competition.

Estuarine fish communities, in particular the estuary associated marine component, depend heavily on mouth state, and for temporarily open and closed estuaries, the frequency, duration and timing of opening events are important (James et al. 2007; Kok \& Whitfield 1986). The near-natural mean annual run-off (Bornman \& Adams 2005) controls the mouth dynamics of the system, 
which allows the migration of fish into and out of the system. The size class frequency distribution of $R$. holubi, L. lithognathus, L. amia, M. falciformis and Mugilidae within the Noetsie Estuary indicates that the estuary serves as both a viable nursery and a feeding area for juveniles. The absence of Myxus capensis and Mugil cephalus from the catches was unusual as these two species comprised 51.9\% and $41.6 \%$ of the catch or $9.7 \%$ and $41.4 \%$ of the biomass, respectively, in a previous study (James \& Harrison 2008). Identifying Muligids to species level would have provided a better understanding of recruitment and usage of the Noetsie Estuary by this family while providing a more robust data set for the EFCI calculations.

The improvement in the EFCI scores from 32 (Harrison \& Whitfield 2006b) to 49 and 46 for the late summer and winter surveys, respectively, pushes the ecological condition category up from 'poor' to 'good'. A significant correlation between EFCI scores and mean EFCI values for systems sampled multiple times suggests that the EFCI is reproducible (Harrison \& Whitfield 2006b) despite variability in fish communities. However, the improvement in score for the Noetsie is more than likely as a result of a more intensive sampling regime and the use of multiple gear types than an actual directional change in ecological condition. However, when utilising the EFCI on a single system over time, it would be beneficial to standardise sampling effort, sampling seasons and gear types to minimise potential biases.

The introduction of alien species is seen as one of the leading causes of biodiversity loss in aquatic ecosystems (Mack et al. 2000). Occurring naturally within south-eastern North America (Pyke 2008), G. affinis has been successfully introduced to most parts of the world (Lloyd 1986). Preferring sheltered, shallow and well-vegetated freshwater habitats (Arthington \& Lloyd 1989), G. affinis are highly tolerant to a wide range of physico-chemical conditions (Pyke 2008) and can occur in waters with temperatures ranging from $0{ }^{\circ} \mathrm{C}$ to $45^{\circ} \mathrm{C}$ (Cherry et al. 1976), salinities from $0 \%$ to $41 \%$ (Hubbs 2000) and dissolved oxygen from $1 \mathrm{mg} \mathrm{L}^{-1}$ to $11 \mathrm{mg} \mathrm{L}^{-1}$ (Odum \& Caldwell 1955). The physico-chemical parameters measured during this and previous surveys of the Noetsie Estuary (Bornman \& Adams 2005; James \& Harrison 2008) were all within the G. affinis tolerance range.

In freshwater environments, G. affinis has been shown to impact ecosystems through both predation on and competition with native biota (Pyke 2008), but little is known about the impacts of G. affinis within estuarine environments. Potential impacts could include predation on juvenile fish and, in particular, the eggs of estuarine resident taxa. Work by Sloterdijk et al. (2015) indicates that in southern Cape estuaries, G. affinis populations seem to undergo a boom and bust scenario, with a rapid increase in abundance over spring and summer and a collapse during winter. Our results suggest G. affinis are limited in distribution to littoral waters and occur in low numbers in the Noetsie Estuary. However, a more detailed study with more sample sites over a longer period would be needed to accurately describe the population characteristics of this invasive species.

\section{Conclusion}

The Noetsie Estuary is important for estuarine resident species while serving as a viable nursery area for estuarineassociated marine species. The species list of fishes utilising the estuary has increased with an additional five indigenous species and one alien invasive freshwater species.

The state of the estuary mouth is the single most important factor driving the ecology in the Noetsie Estuary (Bornman \& Adams 2005), and in turn, mouth dynamics are largely determined by river inflow. Changes in river flow will influence the relationship between open, semi-closed and closed mouth conditions. A decrease in the open and semiclosed phases would limit larval fish recruitment and adult movement out of the estuary, potentially having a negative influence on the associated fish community which should be avoided.

The ecological condition of the Noetsie Estuary is rated as 'good' showing an improvement from a previous assessment of 'poor'. To maintain the condition (or improve it), we recommend that an estuarine management plan be drafted which includes the monitoring and management of river inflows and the potential control or eradication measures needed for the recorded alien species. The plan should also include a sustainable participatory process for stakeholder involvement. We suggest that an estuarine management forum be established, which includes stakeholders influencing or are influenced by river inflows.

Future research should include assessing the change in physico-chemical characteristics and estuarine fish community between stable closed and open phases, as well as directed research assessing the distribution, abundance and ecological impacts of G. affinis throughout the catchment of the Noetsie Estuary.

\section{Acknowledgements}

Bheki Maphanga, Pierre Mouskie, Brian du Preez and Alison Macallister are thanked for assisting with data collection. Wendy Dewberry assisted with logistics, provided background information on Noetsie and helped catalyse this research. Aubrey Wynne-Jones is thanked for covering running costs and providing accommodation. SANParks provided all sampling equipment, and part of the running costs was covered by the Rondevlei Marine Protected Area budget. The two anonymous reviewers are thanked for their positive and helpful comments to improve the manuscript.

\section{Competing interests}

The authors declare that they have no financial or personal relationships which may have inappropriately influenced them in writing this article. 


\section{Authors' contributions}

M.K.S.S. was responsible for the study conceptualisation, data collection, analyses, manuscript writing and editing. D.R. contributed to the study design, data collection, analyses and manuscript editing; and B.C. contributed to the study design and manuscript editing.

\section{References}

Arthington, A.H. \& Lloyd, L.N., 1989, 'Introduced Poeciliidae in Australia and New Zealand', in G.K. Meffe \& F.F. Snelson (eds.), Evolution and ecology of livebearing fishes (Poeciliidae), pp. 33-50, Prentice Hall, New York.

Blaber, S.J.M., Cyrus, D.P. \& Whitfield, A.K., 1981, 'The influence of zooplankton food resources on the morphology of the estuarine clupeid Gilchristella aestuaria (Gilchrist, 1914)', Environmental Biology of Fishes 6, 351-355. https://doi.org/ 10.1007/BF00005764

Bornman, T.G. \& Adams, J.B., 2005, Present state of the Noetsie Estuary, IECM Research Report No. 45, Institute for Environmental and Coastal Management, Nelson Mandela Metropolitan University, Nelson Mandela Bay, 43p.

Cherry, D.S., Guthrie, R.K., Rodgers, J.H., Cairns, J. \& Dickson, K.L., 1976, 'Response of mosquito fish (G. affinis) to ash affluent and thermal stress', Transaction of the American Fisheries Society 105, 686-694. https://doi.org/10.1577/15488659(1976)105\%3C686:ROMGAT\%3E2.0.CO;2

Clarke, K.R. \& Warwick, R.M., 1994, Change in marine communities: An approach to statistical analysis and interpretation, 1st edn., Plymouth Marine Laboratory, Plymouth, UK, 144p.

Department of Water Affairs and Forestry (DWAF), 1995, South African water quality guidelines for coastal marine waters. Volume 1: Natural environment, The Government Printer, Pretoria.

Department of Water Affairs and Forestry (DWAF), 2008, Reserve determination studies for selected surface water, groundwater, estuaries and wetlands in the Outeniqua (Groot Brak and other water resources, excluding wetlands) catchment: Ecological Water Requirement Study - estuarine RDM Report, volume 1.3: Assessment Report RDM/K4O-K50/00/CON/0307, vol. 1, Department of Water Affairs and Forestry, Pretoria.

Hall, C.M., Whitfield, A.K. \& Allanson, B.R., 1987, 'Recruitment, diversity and the influences of constrictions on the distribution of fishes in the Wilderness lakes system, South Africa', South African Journal of Zoology 22, 163-168. https://doi.or $\mathrm{g} / 10.1080 / 02541858.1987 .11448038$

Harrison, T.D., 2001, 'Length-weight relationships of fishes from South African estuaries', Journal of Applied Ichthyology 17, 46-48. https://doi.org/10.1046/ j.1439-0426.2001.00277.x

Harrison, T.D., 2003, 'Biogeography and community structure of fishes in the Southern African Estuaries', PhD thesis, Rhodes University.

Harrison, T.D. \& Whitfield, A.K., 2004, 'A multi-metric fish index to assess the environmental condition of estuaries', Journal of Fish Biology 65, 683-710. https://doi.org/10.1111/j.0022-1112.2004.00477.x

Harrison, T.D. \& Whitfield, A.K., 2006a, 'Estuarine typology and the structuring of fish communities in South Africa', Environmental Biology of Fishes 75, 269-293. https://doi.org/10.1007/s10641-006-0028-y

Harrison, T.D. \& Whitfield, A.K., 2006b, 'Application of a multimetric fish index to assess the environmental condition of South African estuaries', Estuaries and Coasts 29, 1108-1120. https://doi.org/10.1007/BF02781813

Hubbs, C., 2000, 'Survival of Gambusia affinis in a hostile environment', Southwestern Naturalist 45, 521-522. https://doi.org/10.2307/3672601

James, N.C., Cowley, P.D., Whitfield, A.K. \& Lamberth, S.J., 2007, 'Fish communities in temporarily open/closed estuaries from the warm- and cool-temperate regions of South Africa: A review', Reviews in Fish Biol
doi.org/10.1080/00359190809519216

James, N.C. \& Harrison, T.D., 2008, 'A preliminary survey of the estuaries on the south coast of South Africa, Cape St Blaize, Mossel Bay Robberg Peninsula, Plettenberg Bay, with particular reference to the fish fauna', Transactions of the Royal Society of South Africa 63, 111-127. https://doi.org/10.1080/00359190809519216
James, N.C. \& Harrison, T.D., 2010, 'A preliminary survey of the estuaries on the southeast coast of South Africa, Cape St Francis - Cape Padrone, with particular southeast coast of South Africa, Cape St Francis - Cape Padrone, with particular
reference to the fish fauna', Transactions of the Royal Society of South Africa 65 , reference to the fish fauna', Transactions of the Royal
69-84. https://doi.org/10.1080/00359191003652116

Kok, H.M. \& Whitfield, A.K., 1986, 'The influence of open and closed mouth phases on the marine fish fauna of the Swartvlei estuary', South African Journal of Zoology 21, 309-315. https://doi.org/10.1080/02541858.1986.11448004

Lloyd, L., 1986, 'An alternative to insect control by “mosquito fish", Gambusia affinis', Arbovirus Research in Australia 1986, 156-163.

Mack, R.N., Simberloff, D., Lonsdale, W.M., Evans, H., Clout, M. \& Bazzaz, F.A., 2000 'Biotic invasions: Causes, epidemiology, global consequences, and control', Ecological Applications 10, 689-710. https://doi.org/10.1890/1051-0761(2000) 010[0689:BICEGC]2.0.CO;2

National Research Institute for Oceanology (NRIO), 1987, Basic physical geography/hydro data for 'Estuaries' of the Southern Cape (CMS 0-50), NRIO Data Report D8706, Sediment Dynamics Division, Coastal Engineering and Data Report D8706, Sediment Dynamics Division, Coastal Engineering and
Hydraulics, NRIO, Council for Scientific and Industrial Research, Stellenbosch, Hydraul
$18 \mathrm{p}$.

Odum, H.T. \& Caldwell, D.K., 1955, 'Fish respiration in the natural gradient of an anaerobic spring in Florida', Copeia 1955, 104-106. https://doi.org/10.2307/ 1439312

Olds, A.A., James, N.C., Smith, M.K.S. \& Weyl, O.L.F., 2016, 'Fish communities of the Wilderness Lakes System in the southern Cape, South Africa', Koedoe 58(1), a1364. https://doi.org/10.4102/koedoe.v58i1.1364

Olds, A.A., Smith, M.K.S., Weyl, O.L.F. \& Russell, I.A., 2011, 'Invasive alien freshwater fishes in the Wilderness Lakes System, a wetland of international importance in the Western Cape Province, South Africa', African Zoology 46, 179-184. https:// doi.org/10.1080/15627020.2011.11407491

Perissinotto, R., Blair, A., Connell, A., Demetriades, N.T., Forbes, A.T., Harrison, T.D. et al., 2004, 'Literature review: Ecology of South African temporarily open/ closed estuaries: A review of current knowledge', in J.B. Adams (ed.), Contributions to the information requirements for the implementation of resource directed measures for estuaries. Volume 2. Responses of the biological communities to flow variation and mouth state in two KwaZulu-Natal temporarily open/closed estuaries, Water Research Commission Report No. 1247/2/04, pp. 1-55, Water Research Commission, Pretoria.

Pyke, G., 2008, 'Plague Minnow or Mosquito Fish? A review of the biology and impacts of introduced Gambusia species', Annual Review of Ecology, Evolution, and Systematics 39, 171-191. https://doi.org/10.1146/annurev.ecolsys.39.110707. 173451

Russell, I.A., 1996, 'Fish abundance in the Wilderness and Swartvlei lake systems: Changes relative to environmental factors', South African Journal of Zoology 31 , 1-9. https://doi.org/10.1080/02541858.1996.11448389

Sloterdijk, H., James, N.C., Smith, M.K.S., Ekau, W. \& Weyl, O.L.F., 2015, 'Population dynamics and biology of an invasive population of mosquito fish Gambusia affinis in a temperate estuarine lake system', African Zoology 50(1), 31-40. https://doi.or $\mathrm{g} / 10.1080 / 15627020.2015 .1021169$

Whitfield, A.K., 1994, 'An estuary-association classification for the fishes of southern Africa', South African Journal of Science 90, 411-417.

Whitfield, A.K., 1997, 'Fish conservation in South African estuaries', Aquatic Conservation: Marine and Freshwater Ecosystems 7, 1-11. https://doi. org/10.1002/(SICI)1099-0755(199703)7:1\%3C1::AID-AQC213\%3E3.0.CO;2-8

Whitfield, A.K., 1998, Biology and ecology of fishes in Southern African estuaries, Ichthyological Monographs of the J.L.B. Smith Institute of Ichthyology, No 2, Grahamstown, p. 223.

Whitfield, A.K., 2000, Available scientific information on individual southern African estuarine systems, Water Research Commission Report 577/3/00, Water Research Commission, Pretoria, $217 p$.

Whitfield, A.K. \& Elliott, M., 2002, 'Fishes as indicators of environmental and ecological changes within estuaries: A review of progress and some suggestions for the future', Journal of Fish Biology 61, 229-250. https://doi.org/10.1111/j.10958649.2002.tb01773.x

Whitfield, A.K. \& Kok, H.M., 1992, 'Recruitment of juvenile marine fishes into permanently open and seasonally open estuarine systems on the southern coast of South Africa', Ichthyological Bulletin 57, 1-15. 